\title{
Selection of microorganisms and preparation of inoculants with potential applications in the remediation of soil contaminated with hexazinone
}

\section{Vanessa Silva Santos ${ }^{1}$ (D) Paula Fabiane Martins ${ }^{1}$ (i) Lucélia Borgo $^{2}$ (i) Paula Sperotto Alberto Faria ${ }^{1}$ (i) Cintia Faria da Silva ${ }^{1}$ Adriano Jakelaitis ${ }^{1^{*}}$ (1)}

${ }^{1}$ Diretoria de Pós-graduação, Pesquisa e Inovação, Instituto Federal de Educação, Ciência e Tecnologia Goiano (IF Goiano), 75901-970, Rio Verde, GO, Brasil. E-mail: adriano.jakelaitis@ifgoiano.edu.br. "Corresponding author.

${ }^{2}$ Escola Superior de Agricultura "Luiz de Queiroz" (Esalq) Universidade de São Paulo (USP), Piracicaba, SP, Brasil.

ABSTRACT: The excessive use of agrochemicals negatively impacts the environment, making the development of sustainable technologies for the reduction of contaminants in soil necessary. Hexazinone is the herbicide most used for sugarcane crops and persists in the environment. Moreover, its main route of degradation in the soil is through microorganisms. Therefore, six microorganisms were selected that presented growth in the presence of the herbicide; SCR1 - Microbacterium arborescens; SCR2 - Bacillus pumilus; SCM3 - Stenotrophomonas maltophilia; SCM4 - Bacillus cereus; SCM5A - M. arborescens; and SCM5B - B. safensis. A test was performed to evaluate the ability of each lineage in phosphate solubilization. For the $\mathrm{Ca}_{3}(\mathrm{PO})_{2}$, solubilization test, the strains that showed the best results were $B$. pumilus and S. maltophilia. Subsequently, the inoculants were prepared and the concentrations after plating were $2.71 \times 109 C F U \mathrm{~mL}^{-1}$ for $B$. pumilus, $1.02 \times 109 \mathrm{CFU} \mathrm{mL}^{-1}$ for $\mathrm{S}$. maltophilia, and $1.14 \times 1010 \mathrm{CFU} \mathrm{mL}^{-1}$ for a combination of the two strains. These were satisfactory values for use as inoculants.

Key words: bioremediation, Bacillus pumilus, Stenotrophomonas maltophilia, triazinone.

Seleção de microrganismos e preparo de inoculantes com potencial de aplicação na remediação de solo contaminado com hexazinona

RESUMO: $O$ uso de agroquímicos resulta em impactos ambientais e torna-se necessário o emprego de tecnologias sustentáveis para diminuição de contaminantes no solo. O hexazinona é o herbicida mais utilizado para a cultura da cana-de-açúcar, e apresenta persistência no ambiente. A principal via de degradação no solo é por meio de microrganismos. Com isso, selecionou-se seis microrganismos que apresentaram crescimento na presença do herbicida: SCR1 - Microbacterium arborescens; SCR2 - Bacillus pumilus; SCM3 - Stenotrophomonas maltophilia; SCM4 - Bacillus cereus; SCM5A - M. arborescens; SCM5B - Bacillus safensis. Foi realizado um teste para avaliar a habilidade de cada linhagem na solubilização de fosfatos, e no caso da solubilização de Ca3(PO4)2, as linhagens que apresentaram melhores resultados foram B. pumilus e S. maltophilia. Posteriormente, os inoculantes foram preparados e a concentração após plaqueamento de 2,71x109 UFC mL-1 para B. pumilus, 1,02x109 UFC mL-1 para S. maltophilia e consórcio com as duas linhagens 1,14x1010 UFC mL-1 apresentaram valores satisfatórios para utilização como inoculantes.

Palavras-chave: biorremediação, Bacillus pumilus, Stenotrophomonas maltophilia, triazinona.

\section{INTRODUCTION}

Agricultural soils have a microbial diversity that can degrade if under stressful conditions for a prolonged period of time. Therefore, the isolation of microorganisms is beneficial for their use as inoculants to increase the degradation of contaminants (VILLAVERDE et al., 2018).

Soil bio-augmentation, strain introduction, and microbial consortium with the desired catalytic abilities increases the degradation capacity of xenobiotics (MROZIK et al., 2010). Therefore, phytoremediation associated with microorganisms comprises a promising technology for environmental decontamination (SALT et al., 1998). Bacteria can interact with the contaminated environment in different ways, either by promoting plant growth, which favors plants under stress, degrading toxic compounds, or increasing nutrient availability.

Hexazinone is an herbicide of the triazinone chemical group used in sugarcane crops (TONIETO \& REGINATO, 2014). According to 
MARTINS (2015), the study and assessment of the risks of this compound in the environment are relevant because it presents moderate solubility in an aqueous medium. Contamination can occur in a variety of media, including water, soil, and air, resulting in potential risks. The main degradation route of this herbicide in soil is attributed to microorganisms. However, the degradation rate is slow, and the residual activity can extend over several months. WANG et al. (2012) state that the degradation of this molecule is associated with organic carbon content and microbial activity in the soil.

This study selected hexazinone-tolerant microorganisms with phosphate solubilization capacity as well as prepared inoculants to be used in association with plants in the remediation of soil contaminated by hexazinone.

\section{MATERIALS AND METHODS}

\section{Isolation, DNA extraction, and identification}

First, 20 soil samples were collected at a depth of $10 \mathrm{~cm}$ from Rio Verde, $\mathrm{GO}$, at a location $\left(17^{\circ}\right.$ $48^{\prime}$ '28.2" South and 50 54' 39" West, altitude 720 $\mathrm{m})$ with a history of hexazinone application. Samples were homogenized to obtain a composite sample. The microorganisms were isolated from serial dilution, plated from $1 \mathrm{~g}$ of soil, and diluted in $9 \mathrm{~mL}$ of saline solution $(0.85 \%)$.

Plating was performed with $0.1 \mathrm{~mL}$ of each sample being spread on Petri dishes containing nutrient medium (rich medium) with and without herbicide and minimum medium $\left[\left(\mathrm{NH}_{4}\right)_{2} \mathrm{SO}_{4}, 1 \mathrm{~g}\right.$; $\mathrm{NaCl}, 1 \mathrm{~g} ; \mathrm{KH}_{2} \mathrm{SO}_{4}, 1.5 \mathrm{~g} ; \mathrm{MgSO}_{4}, 0.2 \mathrm{~g}$; agar, $15 \mathrm{~g}$ ] with and without herbicide. The treatments without herbicide served as controls. Treatments were entirely randomized in a $4 \times 9$ factorial scheme, consisting of the rich medium with and without herbicide, the minimum medium with and without herbicide, and nine dilutions (up to $10^{9}$ ) with three repetitions.

The herbicide concentration was 4.86 $\mathrm{mL} \mathrm{L}^{-1}$. Plates were incubated at $28{ }^{\circ} \mathrm{C}$ for 24 and $48 \mathrm{~h}$ for rich and minimum medium; respectively, following which the colony forming units (CFUs) were counted. Hexazinone-tolerant bacterial colonies were identified by the presence of a degradation halo and based on the morphological differences observed in the plates containing the herbicide.

Bacterial DNA was extracted using the DNeasy ${ }^{\circledR}$ Blood \& Tissue Kit (Qiagen ${ }^{\circledR}$ ) according to the manufacturer's instructions at the Laboratory of Genetics of Microorganisms of the Luiz de Queiroz School of Agriculture - USP in Piracicaba, São Paulo.
The 16S rDNA gene was amplified by polymerase chain reaction (PCR) using R1387 (CGG TGT GTA CAA GGC GGA ACG) and POF27F (GAG AGT TTG ATC CTG GCT) primers, in reactions with a final volume of $25 \mu \mathrm{L}$ containing $2.5 \mu \mathrm{L}$ of buffer solution, $2.0 \mu \mathrm{L}$ of $\mathrm{MgCl}_{2}, 0.5 \mu \mathrm{L}$ of DNTp, $0.2 \mu \mathrm{L}$ of Taq DNA polymerase, $0.5 \mu \mathrm{L}$ of each primer, and $1 \mu \mathrm{L}$ of the sample. A PCR reaction occurred in a thermal cycler under the following conditions: $95^{\circ} \mathrm{C}$ for $2 \mathrm{~min}$ once $\left(95^{\circ} \mathrm{C}\right.$ for $30 \mathrm{~min}$, $62.5^{\circ} \mathrm{C}$ for $30 \mathrm{~min}, 72^{\circ} \mathrm{C}$ for $1 \mathrm{~min}$, and $72{ }^{\circ} \mathrm{C}$ for 10 $\min 35 \mathrm{x}$ ) and $6^{\circ} \mathrm{C} \infty$ once. DNA was quantified with $1 \mu \mathrm{L}$ of the product by agarose gel electrophoresis $(0.8 \%)$. The PCR product was used for purification with the Illustra GFX PCR DNA kit and Gel Band Purification. The purification product was sequenced in duplicates using the Sanger method in an Applied Biosystems ${ }^{\circledR}$ ABI 3130 sequencer at the Center for Functional Genomics located at the Laboratory of Animal Biotechnology of the Luiz de Queiroz School of Agriculture. The 16S sequences were compared with the GenBank database (http:// www.ncbi.nlm.nih.gov) with sequences known by similarity search via Blastn.

The similarity tree for bacterial isolate identification was built with MEGA 7 software (TAMURA et al., 2013). The Neighbor-Joining algorithm was used with the distance option according to the model proposed by JUKES \& CANTOR (1969), with bacterium sequences being compared to type sequences based on the results of Blastn and the Ribosomal Database Project. The robustness of the similarity tree was confirmed by the analysis of 5,000 bootstrap replicates, and a Burkholderia sp. (AB334766-1) was used as the outgroup.

\section{Microorganism testing for phosphate solubilization}

Pure bacterial cultures isolated from the soil were inoculated in GL culture medium with $10 \mathrm{~g}$ of glucose and $2 \mathrm{~g}$ of yeast extract in $1 \mathrm{~L}$ of distilled water in test tubes, each containing $10 \mathrm{~mL}$ of the medium (SYLVESTER-BRADLEY, 1982). Tubes were maintained on an orbital agitation shaker (110 $\mathrm{rpm}, 28^{\circ} \mathrm{C}$ ) for $24 \mathrm{~h}$ to obtain the pre-inoculum. An aliquot of $1 \mathrm{~mL}$ was used for optical density readings (OD600) in a spectrophotometer.

All bacteria had OD600 (0.5) equated by means of saline dilution $(0.85 \%)$. Insoluble phosphate sources were separately added to each medium; $5 \mathrm{~g} \mathrm{~L}^{-1}$ calcium phosphate $\left[\mathrm{Ca}_{3}\left(\mathrm{PO}_{4}\right)_{2}\right], 1$ $\mathrm{g} \mathrm{L}^{-1}$ iron phosphate $\left(\mathrm{FePO}_{4}\right)$, and $2 \mathrm{~g} \mathrm{~L}^{-1}$ aluminum phosphate $\left(\mathrm{AlPO}_{4}\right)$. Then, $1 \mathrm{~mL}$ of each culture was inoculated in $8 \mathrm{~mL}$ of medium in triplicate (GADAGI 
\& SÁ, 2002) and kept under constant agitation on a pendulum shaking table $\left(\mathrm{TE}-240 / 1, \mathrm{Tecnal}^{\circledR}\right)$ at 100 rpm for $72 \mathrm{~h}$ at $28^{\circ} \mathrm{C}$.

After the growth period, the $\mathrm{pH}$ of the samples was measured and the phosphate solubilization was evaluated using the colorimetric method, in which $2 \mathrm{~mL}$ of the culture was centrifuged at $8,000 \mathrm{rpm}$ for $10 \mathrm{~min}$ at $10^{\circ} \mathrm{C}$. Then, $1 \mathrm{~mL}$ of the supernatant was added to $9 \mathrm{~mL}$ of the working reagent [900 $\mathrm{mL}$ distilled water, $0.4 \mathrm{~g}$ ascorbic acid, and 100 $\mathrm{mL} 725$ solution $(0.1 \mathrm{~g}$ bismuth sub-carbonate, $6.8 \mathrm{~mL}$ sulfuric acid, $30 \mathrm{~mL}$ distilled water, $2.0 \mathrm{~g}$ ammonium molybdate, and $6.8 \mathrm{~mL}$ sulfuric acid for $100 \mathrm{~mL}$ in a volumetric flask)]. After $20 \mathrm{~min}$, spectrophotometer readings were performed at $725 \mathrm{~nm}$. Phosphate solubilization was determined using the phosphoric acid standard curve equation (160 $\left.\mathrm{mg} \mathrm{L}^{-1}\right)$.

\section{Phosphate solubilizer microorganism growth}

The growth curve of the microorganisms selected from phosphate solubilization was determined by inoculating a colony of each bacterium in test tubes maintained in an orbital agitation shaker $\left(110 \mathrm{rpm}, 28^{\circ} \mathrm{C}\right)$ for $24 \mathrm{~h}$. The measured OD600 was 0.6 . Erlenmeyer flasks containing $40 \mathrm{~mL}$ of broth nutrient $(5 \mathrm{~g}$ of peptone and $3 \mathrm{~g}$ of yeast extract in
1 L of distilled water) were inoculated with 400 $\mu 1$ in three repetitions. The OD600 was measured every $2 \mathrm{~h}$ until reaching the stationary phase. CFUs were counted by sample inoculation from plating in different rich media, considering the beginning of the growth and final log phase.

Results were subjected to analysis of variance and the means to Tukey's test $(\mathrm{p}<0.05)$ using Sisvar $^{\mathbb{B}}$ software. Pearson's correlation was used for phosphate solubilization tests between soluble phosphate released by bacteria and the medium $\mathrm{pH}(\mathrm{p}<0.05)$.

\section{RESULTS AND DISCUSSION}

\section{Isolation, DNA extraction, and identification}

CFU count was possible at $10^{2}$ dilution. Only the minimal medium without herbicide treatment differed from the others (Figure 1). There were visual morphological differences in microorganism growth, and the rich medium treatments presented more accelerated growth, forming larger colonies in smaller quantities. Minimum medium treatments presented greater CFU formation, resulting in colonies of smaller diameter compared to those in the rich medium.

CFU growth was inhibited in the presence of herbicides in rich and minimal medium. This

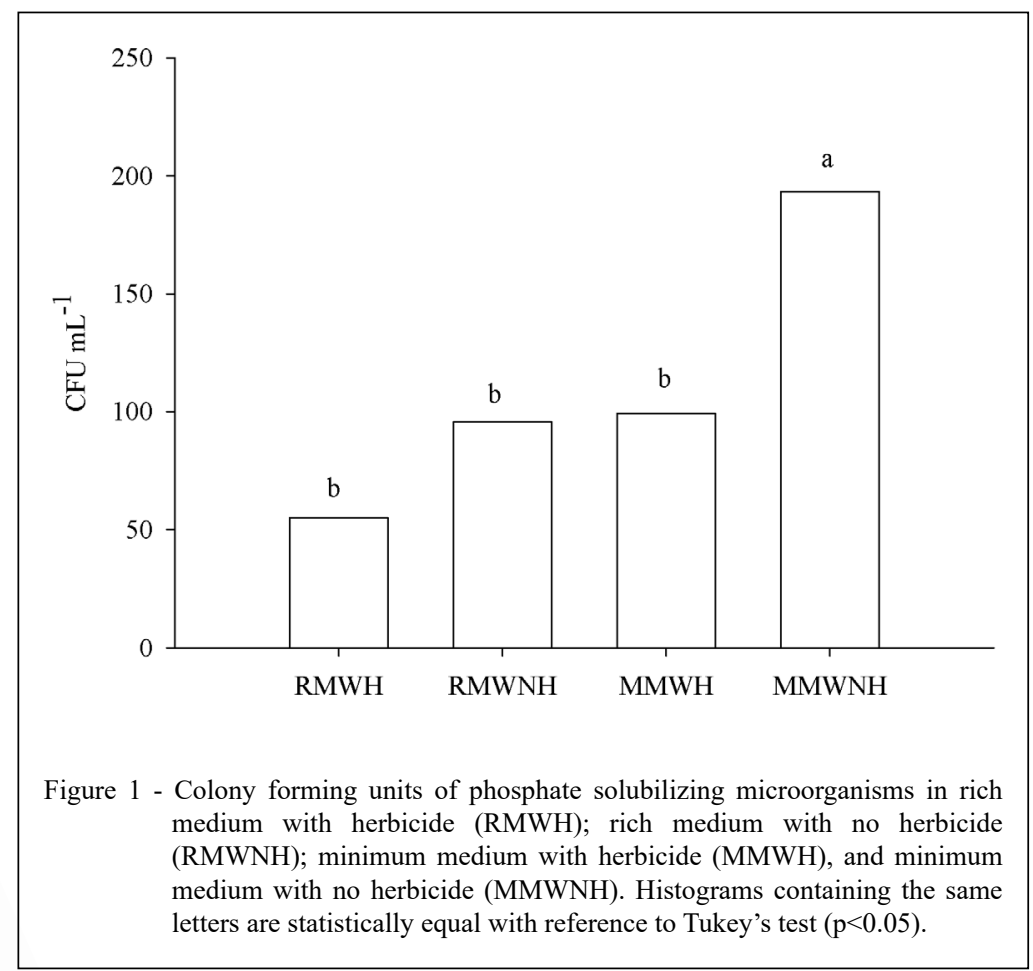

Ciência Rural, v.51, n.6, 2021. 
growth behavior could be related to the generation of reactive oxygen species (ROS) in cells, which increases upon exposure to chemical agents responsible for oxidative damage to cellular tissue (CRAY et al., 2013). Antioxidant enzymes present in microorganisms can be a defense against excessive ROS (GRATA et al., 2005). However, CFUs formed in the presence of the herbicide showed tolerance in rich medium. In the minimum medium, the strains used the herbicide as a nutrient or carbon source.

From the treatments with the herbicide, six CFUs were selected; two from rich medium, potentially tolerant, and four from minimum medium, potentially degrading. The selection parameter was the observation of morphological differences between CFUs grown on plates. The primary isolate identification involved the origin and growth medium used for the microorganism, with SCR-1 and SCR-2 in rich medium and SCM-3, SCM-4, SCM-5A, and SCM- 5B in minimum medium.

The identification of the $16 \mathrm{~S}$ rDNA sequence by similarity analysis compared with the GenBank database (http://www.ncbi.nlm.nih.gov) first identified six strains isolated from the soil, SCR-1, SCR-2, SCM3, SCM-4, SCM-5A, and SCM-5B as Microbacterium arborescens, Bacillus pumilus, Stenotrophomonas maltophilia, Bacillus cereus, M. arborescens, and Bacillus safensis, respectively, with 100\% similarity. The construction of the phylogenetic relationship identified five species (Figure 2). However, it was not possible to insert the species and SCM-5B due to the lower quality of the base pair sequence. However, similarity analysis compared with the GenBank estimated it as B. safensis.

Bacteria of the genus Bacillus can degrade a wide variety of xenobiotics (PINTO et al., 2012). When isolated from soil contaminated with herbicides, tolerance and degradation abilities were observed in tests with several molecules (ZHANG et al., 2018; CUI et al., 2018). Bacillus sp. showed high efficiency in atrazine removal $(90 \%)$ in liquid media (GEED et al., 2017), in addition to increasing plant growth. The genus Microbacterium was investigated for environmental contaminant degradation and detoxification potential (AVRAMOV et al., 2016).

\section{Phosphate solubilization}

Tricalcium phosphate was the most efficient functional feature of solubilization among the tested sources. The maximum solubilization activity of $\mathrm{Ca}_{3}\left(\mathrm{PO}_{4}\right)_{2}$ was reached by the isolates $B$. pumilus (SCR2) and S. maltophilia (SCM-3) with $334.44 \mathrm{~g} \mathrm{~mL}^{-1}$ and $334.30 \mathrm{~g} \mathrm{~mL}^{-1}$, respectively, with acidification of the $\mathrm{pH}$ of the culture medium for both strains, which favored the solubilization effect (Table 1).

A strong, negative $(\mathrm{r}=-0.95)$ and significant $(\mathrm{p}<0.05) \quad$ correlation was observed

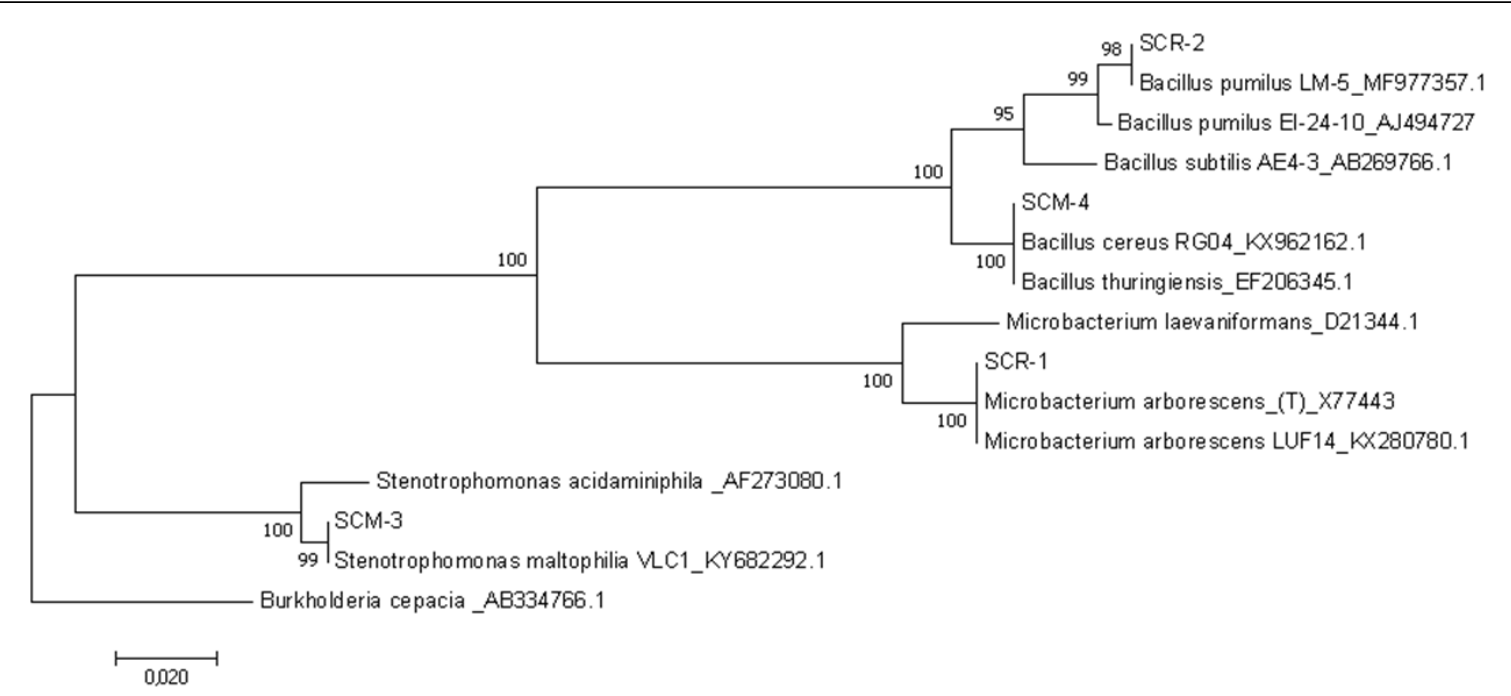

Figure 2 - Similarity analysis based on partial 16S rRNA sequences showing the relationship between bacterial isolates from contaminated soil and some of their closest phylogenetic relatives (indicated by the accession number). Burkholderia cepacia (AB3347661) was used as an external group. 
between the concentration of solubilized tricalcium phosphate and $\mathrm{pH}$, and the more acidic the $\mathrm{pH}$ of the culture medium, the more the inorganic phosphate is solubilized. MERBACH et al. (2009) observed that the calcium phosphate solubilization increases as the $\mathrm{pH}$ decreases. Organic acids produced by microorganisms can facilitate $\mathrm{P}$ solubilization by changing the $\mathrm{pH}$ of the medium (YADAV et al., 2017).

The $\mathrm{FePO}_{4}$ solubilization showed effects on its concentration and the $\mathrm{pH}$ range, with a higher soluble phosphate concentration for the strains B. pumillus (SCR-2), with $271.33 \mathrm{mg}$ $\mathrm{mL}^{-1}$, followed by $B$. cereus (SCM-4), with 258.57 $\mathrm{mg} \mathrm{mL}-1$ (Table 1). $\mathrm{AlPO}_{4}$ showed no solubilization for the evaluated isolates.

The treatments control, $M$. arborescens SCR-1, B. pumillus (SCR-2), and B. cereus (SCM-4) showed a $\mathrm{pH}$ acidification considering that the culture medium with $\mathrm{FePO}_{4}$ has an initial $\mathrm{pH}$ value of 6.5 . However, the treatments $S$. maltophilia (SCM-3), M. arborescens (SCM-5A), and B. safensis SCM$5 \mathrm{~B}$ presented basicity of the medium. The variables insoluble iron phosphate concentration and $\mathrm{pH}$ range showed a negative $(\mathrm{r}=-0.97)$ and significant $(\mathrm{p}<0.05)$ Pearson correlation coefficient. Therefore, iron phosphate is more solubilized as the $\mathrm{pH}$ of the medium is acidified. In this sense, the strains $B$. pumillus (SCR-2), with a $\mathrm{pH}$ of 4.53 , and $B$. cereus (SCM-4), with a $\mathrm{pH}$ of 4.83 , had the highest values of solubilized phosphate.

ANZUAY et al. (2017) studied bacteria of the genus Bacillus and obtained good $\mathrm{FePO}_{4}$ solubilization and a decrease in the $\mathrm{pH}$ of the medium, followed by an increase in biomass through its inoculation in peanut and corn plants. Moreover, RAMANI (2011) observed an increase in phosphate solubilization in Bacillus strains even in the presence of herbicides.

AWAIS et al. (2017) carried out a study with the strain S. Stenotrophomonas maltophilia, isolated from sugarcane rhizosphere, and obtained significant values for the solubilization of calcium phosphates. According to ANZUAY et al. (2015), the amount of phosphate solubilizing bacteria does not change with an increase in pesticides, as they observed an increase in bacteria with this functional trait after the addition of herbicides and insecticides. According to the authors, the microorganism uses these molecules as a source of energy, carbon, and other nutrients in the cellular metabolism (DAS \& DABNATH, 2006).

The strains B. pumillus (SCR-2) and $S$. maltophilia (SEM-3) were tolerant to hexazinone, with a functional trace of tricalcium phosphate solubilization, an important characteristic for soils with a high calcium content. According to KWON et al. (2017), Stenotrophomonas has biotechnological potential due to its metabolism. Also, B. pumillus was cited for having the ability to degrade organic molecules (COSTA et al., 2014) and characteristics for promoting plant growth (MEDINA et al., 2003).

\section{Phosphate solubilizing microorganism growth}

Measurements made at different intervals showed that for B. pumilus, the log phase began after $5 \mathrm{~h}$ of growth, the stationary phase was reached after $15 \mathrm{~h}$, and there was a decrease after $18 \mathrm{~h}$, as shown in figure 3. ANWAR et al. (2009) reported that $B$. pumilus presented brief insecticide degradation with chlorpyrifos at a high cellular density $\left(10^{9} \mathrm{CFU} \mathrm{mL}^{-1}\right)$. However, in lower densities, the degradation was slower, with a $\mathrm{pH}$ condition close

Table 1 - pH and concentrations of tricalcium phosphate $\left(\mathrm{Ca}_{3}\left(\mathrm{PO}_{4}\right)_{2}\right)$ and iron phosphate $\left(\mathrm{FePO}_{4}\right)$ solubilized by bacterial strains isolated from soil contaminated with hexazinone.

\begin{tabular}{|c|c|c|c|c|c|}
\hline ---------- & 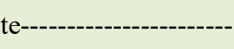 & $\mathrm{Ca}_{3}\left(\mathrm{PO}_{4}\right)_{2} \mathrm{mg} \mathrm{mL}^{-1}$ & $\mathrm{pH}$ & $\mathrm{FePO}_{4} \mathrm{mg} \mathrm{mL}^{-1}$ & $\mathrm{pH}$ \\
\hline Control & & $39.36 \mathrm{a}$ & $6.51 \mathrm{bcd}$ & $241.04 \mathrm{~b}$ & $4.86 \mathrm{~b}$ \\
\hline SCR-1 & M. arborescens & $206.18 \mathrm{c}$ & $5.93 \mathrm{bc}$ & $251.54 \mathrm{bc}$ & $5.02 \mathrm{c}$ \\
\hline SCR-2 & B. pumillus & $334.44 \mathrm{~d}$ & $4.82 \mathrm{a}$ & $271.33 \mathrm{c}$ & $4.53 \mathrm{a}$ \\
\hline SCM-3 & S. maltophilia & $334.30 \mathrm{~d}$ & $4.88 \mathrm{a}$ & $200.67 \mathrm{a}$ & $6.90 \mathrm{f}$ \\
\hline SCM-4 & B. cereus & $176.97 \mathrm{bc}$ & $5.49 \mathrm{~b}$ & $258.57 \mathrm{bc}$ & $4.83 \mathrm{~b}$ \\
\hline SCM- $5^{\mathrm{a}}$ & M. arborescens & $53.87 \mathrm{ab}$ & $6.92 \mathrm{~cd}$ & $197.70 \mathrm{a}$ & $6.57 \mathrm{~d}$ \\
\hline SCM-5B & B. safensis & $49.93 \mathrm{a}$ & $7.05 \mathrm{~d}$ & $196.54 \mathrm{a}$ & $6.71 \mathrm{e}$ \\
\hline $\mathrm{F}$ & & $26.406^{*}$ & $19.488^{*}$ & $58.59^{*}$ & $2393.1^{*}$ \\
\hline $\mathrm{CV}(\%)$ & & 25.53 & 6.08 & 3.13 & 0.65 \\
\hline
\end{tabular}

Means followed by the same letters are statistically equal by the Tukey test $(\mathrm{p}<0.05)$. 


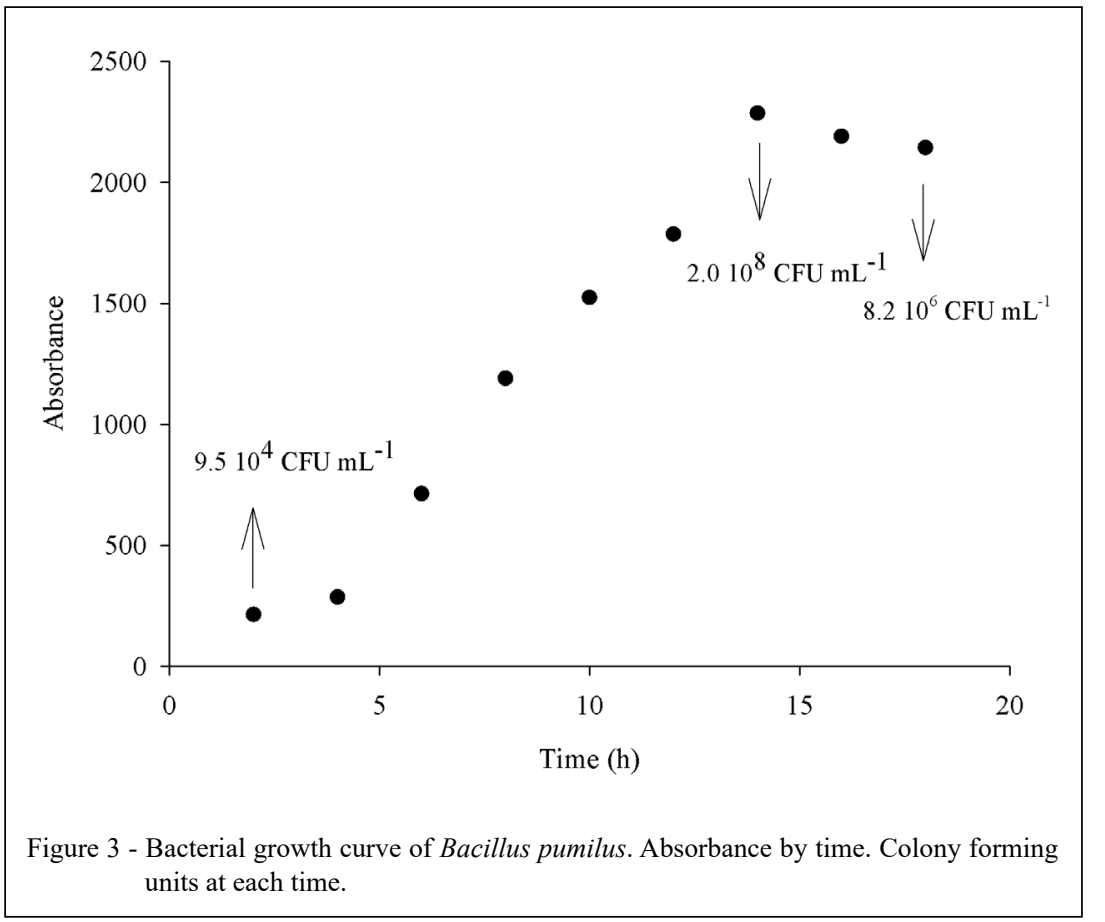

to neutrality. AHMAD et al. (2012) observed the survival of $B$. pumilus in the rhizosphere of ryegrass after inoculation, with increased root area in the presence of the microorganism.
For the S. maltophilia bacterial strain, the log phase was observed after $5 \mathrm{~h}$ of growth and the stationary phase after $14 \mathrm{~h}$, with decreased growth after $21 \mathrm{~h}$ (Figure 4). The genus Stenotrophomonas was reported

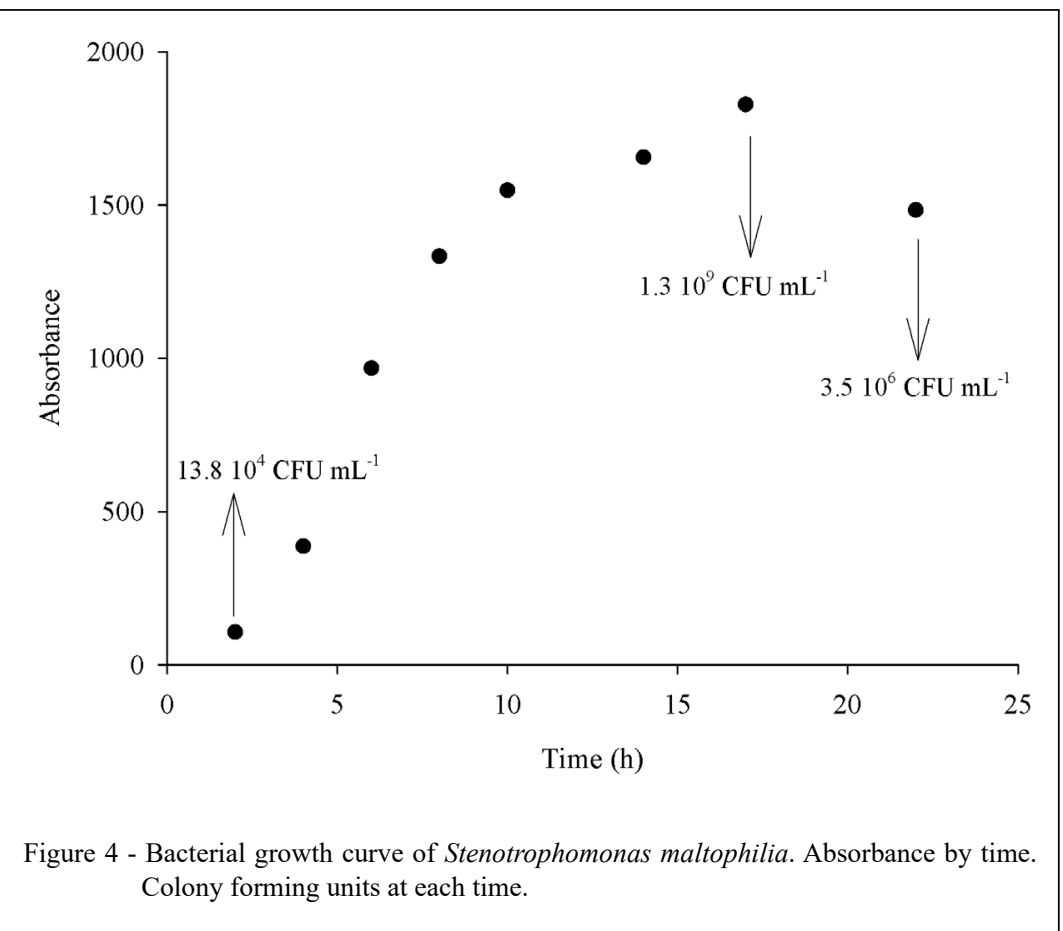

Ciência Rural, v.51, n.6, 2021. 
as a plant growth promoter and biological control agent due to its high metabolite and antifungal enzyme production (ELHALAG et al., 2015). For DUBEY et al. (2012), S. maltophilia has promising applications in bio- and phytoremediation due to genes that metabolize large varieties of organic compounds present in the rhizosphere of plants. It presents efficient xenobiotic (ZHANG et al., 2007), chlorpyrifos (DUBEY et al., 2012), and polyaromatic hydrocarbon degradation (TIWARI et al., 2016; SHUONA et al., 2017).

S. maltophilia can reduce MTBE concentrations (product added to gasoline) in water, and cellular growth increases until $18 \mathrm{~h}$ of incubation. Due to the characteristic genes of the bacteria, which can use the contaminant as the only carbon source, they may have increased growth with a degradation efficiency of 48\% (ALFONSO-GORDILLO et al., 2016).

\section{CONCLUSION}

The isolation of bacteria from soil with a history of use of the herbicide hexazinone allowed selecting and identifying six bacterial isolates with potential for herbicide degradation. Among them, the strains B. pumillus (SCR2) and S. maltophilia (SCM3) stood out for the solubilization of tricalcium and iron phosphates. This research enables a sustainable alternative in agriculture with the use of these strains as soil bioremediators and phosphorus solubilizers, which are important factors for the increase in soil quality and promotion of plant growth.

\section{ACKNOWLEDGMENTS}

The authors thank the Goiano Federal Institute for the financial support and the Coordenação de Aperfeiçoamento de Pessoal de Nível Superior(CAPES), financing code 001.

\section{DECLARATION OF CONFLICT OF INTERESTS}

The authors declare no conflict of interest. The founding sponsors had no role in the design of the study; in the collection, analyses, or interpretation of data; in the writing of the manuscript, and in the decision to publish the results.

\section{AUTHORS' CONTRIBUTIONS}

All authors equally contributed to manuscript design and writing.

\section{REFERENCES}

ALFONSO-GORDILLO, G. et al. Stenotrophomonas maltophilia isolated from gasoline contaminated soil is capable of degrading methyl terc-butyl ether. Electronic Journal of Biotechnology, v.23, p.12-20, 2016. Available from: <https://www.sciencedirect. com/science/article/pii/S0717345816300719>. Accessed: Jun. 19, 2019. doi: 10.1016/j.ejbt.2016.06.006.

AHMAD, F. et al. Enhanced remediation of chlorpyrifos from soil using ryegrass (Lollium multiflorum) and chlorpyrifosdegrading bacterium B. pumilus $\mathrm{C} 2 \mathrm{~A} 1$. Journal Of Hazardous Materials, v.237, p.110-115, 2012. Available from: $<\mathrm{https}: / / \mathrm{www}$. sciencedirect.com/science/article/abs/pii/S0304389412008126>. Accessed: Jun. 19, 2019. doi: 10.1016/j.jhazmat.2012.08.006.

ANWAR, S. et al. Biodegradation of chlorpyrifos and its hydrolysis product 3,5,6-trichloro-2-pyridinol by B. pumilus strain C2A1. Journal of Hazardous Materials, v. 168, p.400-405, 2009. Available from: <https://www.sciencedirect.com/science/article/ abs/pii/S0304389409002441>. Accessed: Aug. 20, 2018. doi: 10.1016/j.jhazmat.2009.02.059.

ANZUAY, M. S. et al. Effect of pesticides application on peanut (Arachis hypogaea L.) associated phosphate solubilizing soil bacteria. Applied Soil Ecology, v.95, p.31-37, 2015. Available from: <https://www.sciencedirect.com/science/article/abs/pii/ S092913931530007X>. Accessed: Aug. 20, 2018. doi: 10.1016/j. apsoil.2015.05.003.

ANZUAY, M. S. et al. Growth promotion of peanut (Arachis hypogaea L.) and maize (Zea mays L.) plants by single and mixed cultures of efficient phosphate solubilizing bacteria that are tolerant to abiotic stress and pesticides. Microbiological Research, v.199, p.98-109, 2017. Available from: <https://www.sciencedirect.com/ science/article/pii/S0944501317300241>. Accessed: Jan. 25, 2018. doi: 10.1016/j.micres.2017.03.006.

AVRAMOV, P. et al. Draft genome sequence of Microbacterium oleivorans strain Wellendorf implicates heterotrophic versatility and bioremediation potential. Genomics Data, v.10, p.54-60, 2016. Available from: <https://www.sciencedirect.com/science/ article/pii/S2213596016301209>. Accessed: Jun. 16, 2019. doi: 10.1016/j.gdata.2016.09.005.

AWAIS, M. et al. Isolation, characterization and inter-relationship of phosphate solubilizing bacteria from the rhizosphere of sugarcane and rice. Biocatalysis and Agricultural Biotechnology, v.11, p.312-321, 2017. Available from: $<$ https://www.sciencedirect.com/ science/article/abs/pii/S1878818117304000>. Accessed: May, 7, 2019. doi: 10.1016/j.bcab.2017.07.018.

COSTA, S. P. et al. Vegetative cells of Bacillus pumilus entrapped in chitosan beads as a product for hydrocarbon biodegradation. International Biodeterioration \& Biodegradation, v.87, p.122127, 2014. Available from: <https://www.sciencedirect.com/ science/article/pii/S0964830513004216>. Accessed: May, 10, 2019. doi: 10.1016/j.ibiod.2013.11.011.

CRAY, J. A. et al. The biology of habitat dominance; can microbes behave as weeds? Microbial Biotechnology, v.6, p.453-492, 2013. Available from: $<$ https://sfamjournals.onlinelibrary.wiley.com/doi/ epdf/10.1111/1751-7915.12027>. Accessed: Jun. 19, 2018. doi: 10.1111/1751-7915.12027.

CUI, N. et al. Microbial degradation of fomesafen and detoxification of fomesafen-contaminated soil by the newly isolated strain Bacillus sp. FE-1 via a proposed biochemical degradation pathway. Science of the Total Environment, v.616, p.1612-1619, 2018. Available from: <https://www.sciencedirect.com/science/article/ 
pii/S0048969717328619>. Accessed: Jun. 7, 2019. doi: 10.1016/j. scitotenv.2017.10.151.

DAS, A. C.; DEBNATH, A. Effect of systemic herbicides on $\mathrm{N}_{2}$ fixing and phosphate solubilizing microorganisms in relation to availability of nitrogen and phosphorus in paddy soils of West Bengal. Chemosphere, v.65, p.1082-1086, 2006. Available from: <https:// www.sciencedirect.com/science/article/pii/S0045653506002542>. Accessed: May, 19, 2019. doi: 10.1016/j.chemosphere.2006.02.063.

DUBEY, K. K.; FULEKAR, M. H. Chlorpyrifos bioremediation in Pennisetum rhizosphere by a novel potential degrader Stenotrophomonas maltophilia MHF ENV20. World Journal of Microbiology and Biotechnology, v.28, p.1715-1725, 2012. Available from: <https://link.springer.com/article/10.1007\%2 Fs11274-011-0982-1>. Accessed: Sep. 10, 2019. doi: 10.1007/ s11274-011-0982-1.

ELHALAG, K. M. et al. The relation of different crop roots exudates to the survival and suppressive effect of Stenotrophomonas maltophilia (PD4560), biocontrol agent of bacterial wilt of potato. Journal of Phytopathology, v.163, p.829-840, 2015. Available from: <https://onlinelibrary.wiley.com/doi/full/10.1111/ jph.12381>. Accessed: May, 19, 2019. doi: 10.1111/jph.12381.

GADAGI, R. S.; SA, T. New isolation method for microorganisms solulbilizing iron and aluminum phosphates using dyes. Soil Science and Plant Nutrition, v.48, p.615-618, 2002 Available from: <https://www.tandfonline.com/doi/abs/10.10 80/00380768.2002.10409246>. Accessed: May, 18, 2018. doi: 10.1080/00380768.2002.10409246.

GEED, S. R. et al. Assessment of pesticides removal using twostage Integrated Aerobic Treatment Plant (IATP) by Bacillus sp. isolated from agricultural field. Bioresource Technology, v.242, p.45-54, 2017. Available from: <https://www.sciencedirect.com/ science/article/pii/S0960852417303528>. Accessed: May, 19, 2019. doi: 10.1016/j.biortech.2017.03.080.

GRATA, P. L. et al. Making the life of heavy metal stressed plants a little easier. Functional Plant Biology, v.32, p.481-494, 2005. Available from: <https://www.publish.csiro.au/fp/FP05016>. Accessed: May, 19, 2019. doi: 10.1071/FP05016.

JUKES, T. H.; CANTOR, C. R. Evolution of protein molecules. Mammalian Protein Metabolism, v.3, p.132, 1969.

KWON, H. T. et al. Complete genome sequence of Stenotrophomonas sp. KCTC 12332, a biotechnological potential bacterium. Journal of Biotechnology, v.256, p.27-30, 2017. Available from: <https://www.sciencedirect.com/science/article/ pii/S0168165617315122>. Accessed: Jan. 12, 2019. doi: 10.1016/j. jbiotec.2017.06.1207.

MARTINS, A. S. et al. Simultaneous degradation of diuron and hexazinone herbicides by photo-fenton: assessment of concentrations of $\mathrm{H} 2 \mathrm{O} 2$ and $\mathrm{Fe} 2+$ by the response surface methodology. Journal of Advanced Oxidation Technologies, v.18, p.9-14, 2015. Available from: <https://www.degruyter.com/ view/j/jaots.2015.18.issue-1/jaots-2015-0101/jaots-2015-0101. xml>. Accessed: May, 19, 2019. doi: 10.1515/jaots-2015-0101.

MEDINA, A. et al. Interactions of arbuscular-mycorrhizal fungi and Bacillus strains and their effects on plant growth microbial rhizosphere activity (thymidine and leucine incorporation) and fungal biomass (ergosterol and chitin). Applied Soil Ecology, v.22, p.15-28, 2003. Available from: <https://www.sciencedirect. com/science/article/abs/pii/S0929139302001129>. Accessed: May, 19, 2019. doi: 10.1016/S0929-1393(02)00112-9.

MERBACH, W. et al. Influence of rhizosphere bacteria of African oil palm (Elaeis guineensis) on calcium, iron, and aluminum phosphate in vitro mobilization. In: INTERNATIONAL SYMPOSIUM "ROOT RESEARCH AND APPLICATIONS", Anais..., 2009. p.2-4. Available from: <https://s3.amazonaws. com/academia.edu.documents/42005465/Influence_of rhizosphere bacteria of Afr20160203-5553-ybtr5j.pdf?responsecontent-disposition=inline $\% 3 \mathrm{~B} \% 20$ filename $\% 3$ DInfluence_of_ rhizosphere bacteria of Afr.pdf\&X-Amz-Algorithm=AWS4HMAC-SHĀ256\&X-Āmz-Credential=AKIAIWOWYYGZ2Y53 UL3A\%2F20200223\%2Fus-east-1\%2Fs3\%2Faws4 request\&XAmz-Date $=20200223$ T203730Z \&X-Amz-Expires $=3600 \& X-$ Amz-SignedHeaders $=$ host $\& X-A m z-$ Signature $=072 \mathrm{c} 9 \mathrm{c} 863 \mathrm{~d} 2 \mathrm{ba}$ fb0f2357aa3686efe64997beb65a99d7f37e55ae90750e81797>. Accessed: May, 12, 2019.

MROZIK, A.; PIOTROWSKA-SEGET, Z. Bioaugmentation as a strategy for cleaning up of soils contaminated with aromatic compounds. Microbiological Research, v.165, p.363-375, 2010. Available from: <https://www.sciencedirect.com/science/ article/pii/S0944501309000585>. Accessed: May, 12, 2019. doi: 10.1016/j.micres.2009.08.001.

PINTO, A. et al. Degradation of terbuthylazine difenoconazole and pendimethalin pesticides by select fungi cultures. Science of the Total Environment, v.435, p.402-410, 2012. Available from: <https:// www.sciencedirect.com/science/article/pii/S0048969712009722>. Accessed: Aug. 10, 2018. doi: 10.1016/j.scitotenv.2012.07.027.

RAMANI, V. Effect of pesticides on phosphate solubilization by Bacillus sphaericus and Pseudomonas cepacia. Pesticide Biochemistry and Physiology, v.99, p.232-236, 2011. Available from: $<$ https://www. sciencedirect.com/science/article/abs/pii/S0048357511000034>. Accessed: May, 11, 2018. doi: 10.1016/j.pestbp.2011.01.001.

SALT, D. E. Phytoremediation. Annual Review of Plant Physiology and Plant Molecular Biology, v.49, p.643-668, 1998. Available from: <https:/www.annualreviews.org/doi/pdf/10.1146/ annurev.arplant.49.1.643>. Accessed: Jan. 2, 2019.

SHUONA, C. et al. Physiology and bioprocess of single cell of Stenotrophomonas maltophilia in bioremediation of co-existed benzo[a]pyrene and copper. Journal of Hazardous Materials, v.321, p.9-17, 2017. Available from: <https://www.sciencedirect. com/science/article/abs/pii/S0304389416308056>. Accessed: Apr. 1, 2019. doi: 10.1016/j.jhazmat.2016.09.002.

SYLVESTER-BRADLEY, R. et al. Quantitative survey of phosphate solubilizing microorganisms in the rhizosphere of grasses and forage legumes in the Amazon. Acta Amazônica, v.12, n.1, p.15-22, 1982. Available from: <http://www.scielo.br/pdf/aa/ v12n1/1809-4392-aa-12-1-0015.pdf $>$. Accessed: May, 12, 2019. doi: 10.1590/1809-43921982121015.

TAMURA, K. et al. MEGA6: molecular evolutionary genetics analysis version 6.0. Molecular Biology and Evolution, v.30, n.12, p.2725-2729, 2013. Available from: <https://academic.oup. com/mbe/article/30/12/2725/1017851>. Accessed: May, 19, 2019. doi: $10.1093 / \mathrm{molbev} / \mathrm{mst} 197$.

TIWARI, B. et al. Biodegradation and dissolution of polyaromatic hydrocarbons by Stenotrophomonas sp. Bioresource Technology, 
v.216, p.1102-1105, 2016. Available from: <https://www. sciencedirect.com/science/article/pii/S0960852416308641> Accessed: Jul. 15, 2018. doi: 10.1016/j.biortech.2016.06.047.

TONIETO, T.; REGINATO, J. Effects of straw decomposition degree on leaching and weed control efficacy of tebuthiuron and hexazinone in green sugarcane harvesting. Planta Daninha, v.32, n.4, p.808-815, 2014. Available from: <http://www.scielo.br/pdf/ pd/v32n4/16.pdf>. Accessed: Jan. 2, 2019. doi: 10.1590/S010083582014000400016 .

VILLAVERDE, M. et al. Combined use of isolated microbial consortia of different agricultural soils and cyclodextrin as a bioremediation technique for soils contaminated with herbicides. Chemosphere, v.193, p.118-125, 2018. Available from: $\quad<\mathrm{https} / / / \mathrm{www}$. sciencedirect.com/science/article/ pii/S0045653517317587>. Accessed: May, 19, 2019. doi: 10.1016/j.chemosphere.2017.10.172.

WANG, $\mathrm{H}$. et al. Modification to degradation of hexazinone in forest soils amended with sewage sludge. Journal of Hazardous Materials, v.200, p.96-104, 2012. Available from: <https://www.
sciencedirect.com/science/article/abs/pii/S0304389411013136>. Accessed: Nov. 9, 2019. doi: 10.1016/j.jhazmat.2011.10.073.

YADAV, H. et al. Improving the applicability of rock phosphate to alkaline soils by organic compost. Applied Soil Ecology, v.113, p.80-85, 2017. Available from: <https://www.sciencedirect.com/ science/article/abs/pii/S0929139317301464>. Accessed: Aug. 12, 2019. doi: 10.1016/j.apsoil.2017.02.004

ZHANG, J. F. et al. Preparation of 3-ketovalidoxylamine A C-N lyase substrate: N-p-nitrophenyl-3-ketovalidamine by Stenotrophomonas maltophilia. Applied Microbiology and Biotechnology, v.73, p.1275-1281, 2007. Available from: <https:// link.springer.com/article/10.1007/s00253-006-0619-8>. Accessed: May, 19, 2019. doi: 0.1007/s00253-006-0619-8.

ZHANG, J. et al. Detoxification of diphenyl ether herbicide lactofen by Bacillus sp. Za and enantioselective characteristics of an esterase gene LacE. Journal of Hazardous Materials, v.341, p.336-345, 2018. Available from: < https://www.sciencedirect.com/ science/article/abs/pii/S0304389417305733>. Accessed: May, 19, 2019. doi: 10.1016/j.jhazmat.2017.07.064. 